Note-Cotton and the Great Divergence: The Asian Fibre that made Europe Rich

\title{
Giorgio Riello
}

\section{(2) OpenEdition Journals}

Electronic version

URL: https://journals.openedition.org/eastafrica/319

DOI: $10.4000 /$ eastafrica.319

ISSN: 2790-1076

\section{Publisher}

IFRA - Institut Français de Recherche en Afrique

\section{Printed version}

Date of publication: 1 March 2016

Number of pages: 63-76

ISSN: 2071-7245

\section{Electronic reference}

Giorgio Riello, "Note-Cotton and the Great Divergence: The Asian Fibre that made Europe Rich", Les Cahiers d'Afrique de l'Est / The East African Review [Online], 51 | 2016, Online since 13 September 2019 connection on 09 December 2021. URL: http://journals.openedition.org/eastafrica/319 ; DOI: https:// doi.org/10.4000/eastafrica.319 


\section{Note - Cotton and the Great Divergence: The Asian Fibre that made Europe Rich}

\section{Giorgio Riello}

Today the world textile and garment trade amounts to a staggering 425 billion US\$ in value. We are told that under the pressure of increasing globalisation, it is Asia - India, China and Turkey in particular - that is the new world manufacturing powerhouse. However the recent growth of Asia into the world's leading textile manufacturer is not a new phenomenon. Until the industrial revolution at the end of the eighteenth century, both India and China were leading economic areas and their skills in cotton textile manufacturing were far superior to those of Europe. Asia manufactured great quantities of colourful printed and painted cottons that were sold across the Indian Ocean and reached faraway places such as Japan and Europe where they were craved as exotic fashionable goods.

Historians have argued that this ensured for Asia - and in particular India - widespread prosperity, as well as high rates of economic growth and technological development, but that sometime after 1750 Europe experienced a sudden and radical economic transformation: the continent industrialised. Mechanisation was first experienced in the textile sector. The spinning machine allowed one late eighteenth-century European woman to produce as much yarn as 300 women in India. By the early decades of the nineteenth century, India, China and the Ottoman Empire switched from being world producers to being buyers of European cotton textiles, a position that they retained for the following two centuries.

My book Cotton (2013) and Sven Beckert's Empire of Cotton (2015) have argued that unlike other commodities such as cod or salt, cotton came to transform the global economy: with differing emphases, both books claim that cotton and cotton textiles were not just commodities with a global appeal or products that drew on global networks of labour, materials and knowledge. ${ }^{1}$ Cotton came to reshape the relationship between different areas of the world, transformed productive processes, created new systems of capital and labour and significantly innovated technologies.

Notwithstanding the simplicity of this narrative and the global role that cotton and cotton textiles had over centuries, most historians are far more familiar with the role of cotton in the process of industrialization of Europe. Students sometimes seem to ignore that cotton was not a fibre grown in Europe and that Lancashire did not have cotton plantations.

I wish to turn first to the issue of industrialization to reassess the role played by cotton textiles. My argument is that the story of cotton should be interpreted as one of economic

\footnotetext{
${ }^{1}$ Giorgio Riello, Cotton: The Fabric that Made the Modern World (Cambridge: Cambridge University Press, 2013); Sven Beckert, Empire of Cotton: A Global History (London: Vintage, 2015). My book developed over the years through the activities of a network coordinated by Patrick O'Brien at the London School of Economics and entitled The Global Economic History Network project (GEHN) funded by the Leverhulme Trust: http://www2.lse.ac.uk/economicHistory/Research/GEHN/ Home.aspx. Among the results of this network were two volumes, both published in 2009. Giorgio Riello and Prasannan Parthasarathi, eds., The Spinning World: A Global History of Cotton Textiles, 1200-1850 (Oxford: Oxford University Press, 2009); and Giorgio Riello and Tirthankar Roy, eds., How India Clothed the World: The World of South Asian Textiles (Leiden: Brill, 2009).
} 
development broadly defined. In particular, cotton textiles can help us to explain the gap between richer and poor parts of the globe a topic that is closely linked to the issue of economic divergence that has dominated debates in global history in the last decade. However, in my work on cotton textiles I have also attempted to de-emphasise the disruptive nature of divergence as conceptualized by Kenneth Pomeraz and his followers (and indeed critics) to emphasise instead continuities across time. ${ }^{2}$

In essence this means a re-assessment of the meaning of the British industrial revolution (and European industrialization), something that in my work is not seen as a sudden and deep transformation of manufacturing (the adoption of new technologies and the high economic growth that this ensued) but more a process of economic and socio-cultural transformation that was as reliant on factors endogenous to Europe as it was on external stimuli.

\section{Cotton and the Industrial Revolution}

Let me start therefore by considering a traditional narrative that posits that Europe (and Britain in particular) became rich (developed and industrialised) because of an industrial revolution based on cotton. Eric Hobsbawn was eloquent and forceful in equal measure when he said "Whoever says Industrial Revolution, says cotton". 3

Indeed this is the message reiterated in dozens of economic history textbooks. But the association between cotton and industrialisation is not new and has not been created by historians. Nineteenth-century commentators already posited it as a truism and their explanation was accepted in places as far away from Britain as Japan (Figure 1).

This image is part of several dozen such prints produced in the 1870s and mostly deals with the subject of the relationship between Japan and the West. With the opening of Japan's borders in the 1860s, a wave of 'Occidentalism' gripped the country as Japanese people wanted to know more about the West. Prints were produced on a varied range of topics that include Thomas Carlyle, the modernity of the United States, and the exoticism of European dress, among the many. The caption says the Englishman represented in the image "struggled with making a machine to spin a cotton yarn for several years, which made his family impoverished.

\footnotetext{
${ }^{2}$ Kenneth Pomeranz, The Great Divergence: China, Europe and the Making of the Modern World Economy (Princeton: Princeton University Press, 2000). On the critique of divergence see: P.H.H. Vries, "Are Coal and Colonies Really Crucial? Kenneth Pomeranz and the Great Divergence," Journal of World History 12/2 (2001): 407-46; Prasannan Parthasarathi, "Review Article: The Great Divergence," Past \& Present 167 (2002): 275-93. Recent contributions that revise the concept of divergence are: Prasannan Parthasarathi, Why Europe Grew Rich and Asia did Not: Global Economic Divergence, 1600-1850 (Cambridge: Cambridge University Press, 2011); Jean-Laurent Rosenthal and R. Bin Wong, Before and Beyond Divergence: The Politics of Economic Change in China and Europe (Cambridge MA: Harvard University Press, 2011); Peer Vries, Escaping Poverty: The Origins of Modern Economic Growth (Vienna: Vienna University Press, 2013); Id., State, Economy and the Great Divergence: Great Britain and China, 1680s-1850s (London: Bloomsbury, 2015). For critical assessments, see: Joseph M. Bryant, 'The West and the Rest Revisited: Debating Capitalist Origins, European Colonialism, and the Advent of Modernity," Canadian Journal of Sociology 31/4 (2006): 403-44; Patrick K. O’Brien, "Historical Foundations for a Global Perspective on the Emergence of a Western European Regime for the Discovery, Development, and Diffusion of Useful and Reliable Knowledge”, Journal of Global History, 8/1 (2013): 1-24; Shami Ghosh, “The 'Great Divergence,' Politics, and

64 Capitalism", Journal of Early Modern History, 19/1 (2015): 1-43.

${ }^{3}$ Eric Hobsbawm, Industry and Empire: From 1750 to the Present Day (London: Penguin, 1999), p. 34.
} 


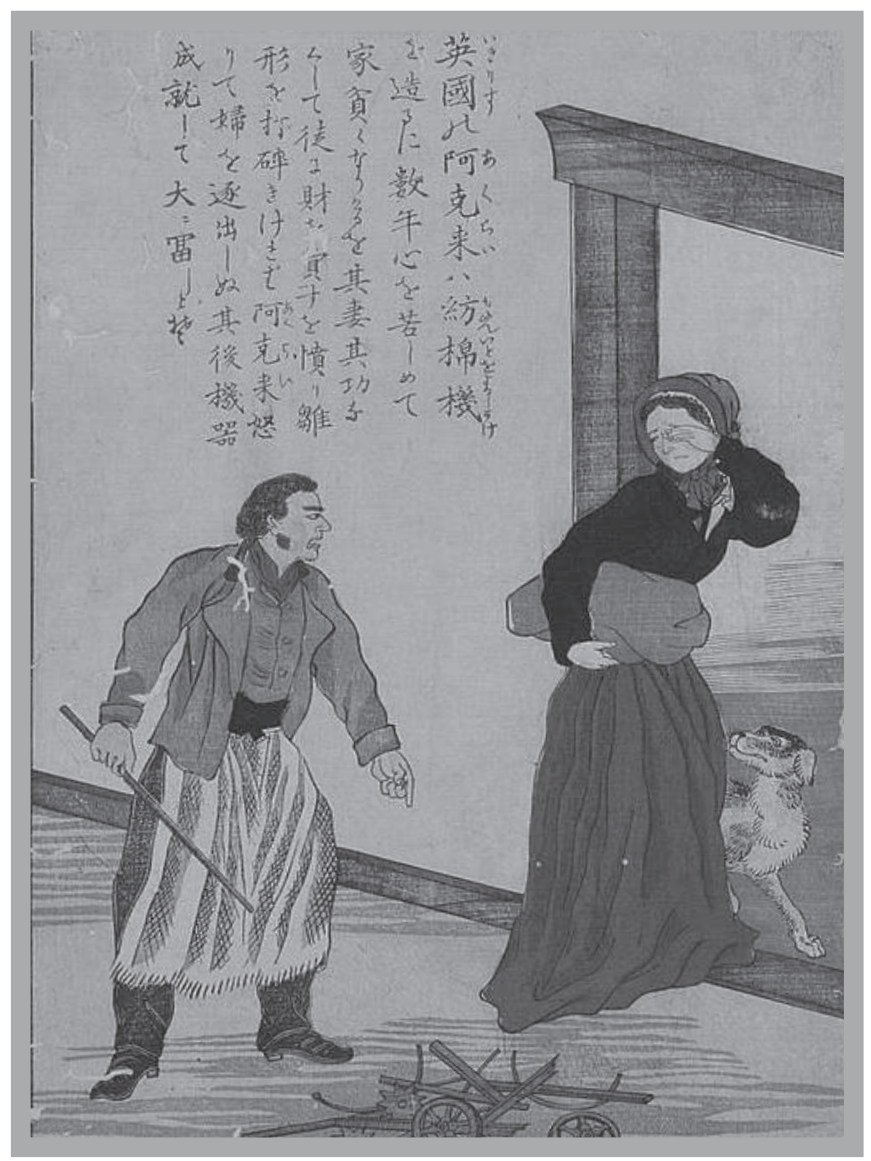

Figure 1. Sir Richard Arkwright, inventor of the spinning machine, second half of the nineteenth century. Chadbourne collection of Japanese prints, Library of Congress. hōsho paper. LC: FP 2 - Chadbourne, no. 30 .

Seeing him wasting money without success, driven by the anger, his wife broke a scale model. Arkwright got so mad at her that he kicked her out of the house. After that event, he successfully invented the machine and made fortunes on it."

The scene represents the famous inventor sending his wife to her parents as she deliberately broke his machine. The main character of such a story was none other than Sir Richard Arkwright, the inventor of the waterframe, the first mechanical spinning machine patented in 1769 in England. The machine was actually much bigger than represented in the print, and the story goes that it was not the wife to destroy it, but that there was fear in the 1770s that a mob might want to destroy it as it put out of work hundreds of workers, mostly female spinners.

\footnotetext{
4 国（いきりす）の阿克来（あくらい）八紡棉機（もめんいとをよるしかけ）/を造るに數年心を苦 しめて

家貧くなりけるを其妻其功な/くして徒に財を費すを憤り雛 / 形を打砕きけれは阿克来（あ くらい) 怒

りて婦を逐出しぬ其後機器/成就して大ニ富りとそ. See Riello, Cotton, pp 211-13.
} 
What is surprising is that power of the figure of the 'heroic inventor' allows the story to be transposed for an audience at the other side of Eurasia. It is also adapted to fit a familial context of conjugal disharmony, a situation that would have resonated better in a nation not yet industrialised than an image representing factories and the English working class. This amusing image is also a reminder that the story of cotton is one that has long been set in the eighteenth century, heavily reliant on technological innovation and application, and above all, that it is a narrative that is quintessentially English. All of this seems at odds with the fact that cotton textile manufacturing had been a major sector of many economies across the world for the best part of half a millennium before Arkwright invented his celebrated machine. How is one to tell the long story of the economic engagement with cotton textile production without narrating it as the prequel to the industrial revolution or as a cavalcade across the centuries towards the ineluctable capitalist development of textile production?

\section{Cotton and its Long History}

Although cotton cultivation and its transformation into cloth was already a developed sector before the Common Era, it was around year $1000 \mathrm{CE}$ that cotton textile production developed into a large-scale economic sector in several areas of the Afro-Eurasian landmass. During the period from the eleventh to the sixteenth century the production and trade of cotton textiles achieved global relevance and several regions of South Asia gained international domination with their production. Cottons were traded by Indian and other merchants and were eagerly purchased by consumers who appreciated their colours, design and material properties. One can see a process of 'globalisation' of cotton textiles that is not just important per se, but also significant in supporting the intensification of global trade and cultural encounters especially in the period between 1400 and $1800 .{ }^{5}$ By the European later middle ages, Indian cotton textiles were a common item of apparel and furnishing in many regions within the Indian Ocean and beyond, from Southeast Asia to West Africa, Japan, and Europe. Eventually the use of cotton textiles became commonplace across the Atlantic both in Latin and North America (Figure 2) ${ }^{6}$ The trade of finished goods (yarn but more commonly cloth) coincided also with the spread of cotton cultivation and associated technologies (for cleaning cotton and spinning it). Many areas of the world became producers of cottons in their own right.

Yet whilst several areas of the world - most notably Eastern China, parts of Southeast Asia, West Africa and the Ottoman Empire - produced cotton textiles, it was India that excelled globally in their production. ${ }^{7}$

I call this a period of the 'The First Cotton Revolution'. In this period India was the core of a global system that was only loosely coordinated by the Subcontinent. Whilst enjoying the competitive advantage provided by the high quality of local production, most

${ }^{5}$ Giorgio Riello, The Globalization of Cotton Textiles: Indian Cottons, Europe, and the Atlantic World, 1600-1850. In Riello and Parthasarathi, eds., Spinning World, pp. 261-87.

${ }^{6}$ See the recent contribution by Robert DuPlessis, The Material Atlantic: Clothing, Commerce, and Colonization in the Atlantic World, 1650-1800 (Cambridge: Cambridge University Press, 2015).

$66{ }^{7}$ See in particular Giorgio Riello and Tirthankar Roy, Introduction: The World of South Asian Textiles, 1500-1850. In Riello and Roy, eds., How India Clothed the World, pp. 1-27. 


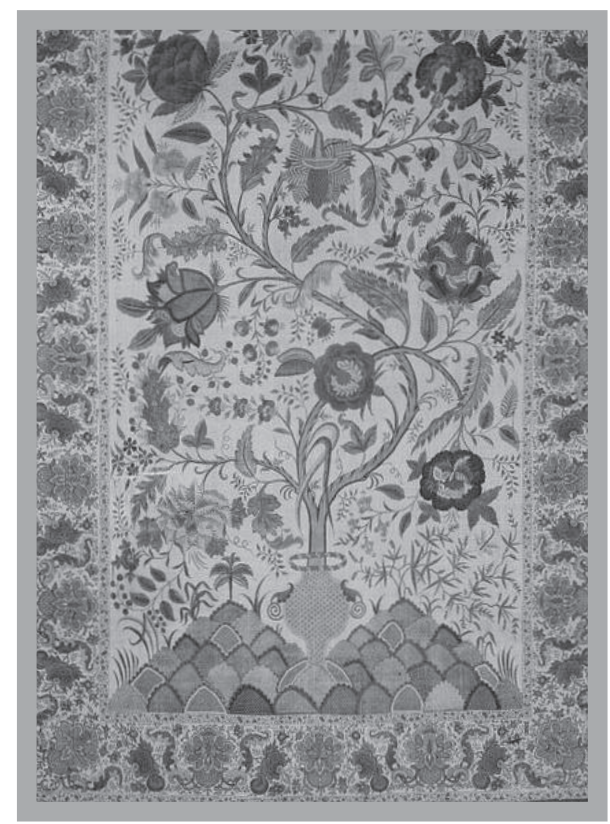

Figure 2. A large palampore produced on the Coromandel Coast for the European market, c. 1720-40. 307 x $248 \mathrm{~cm}$. Victoria and Albert Museum, IS.36-1950. Given by G.P. Baker.

These types of large and beautifully painted Indian cloths were particularly popular in Europe and North America in the seventeenth and eighteenth centuries.

of the areas with which India interacted engaged in their own right in the cultivation of raw cotton, its processing and manufacturing into cloth. Together they formed a system of competition as well as symbiosis. Trade was structured through networks of Asian intermediaries and consumers were keen to mix local and exotic commodities, the latter being often customised in accordance with tastes and local meanings attributed to cloth. Cotton textiles were central to the articulation of a global system structuring itself mostly through 'nodes' of trade.

India indeed emerged as a core area but its position was over time weakened by processes of osmosis dominated by what I call a 'centrifugal' logic: resources, technologies and commodities tended to diffuse across the system described. This was the case from at least three points of view.

First, in terms of materials: cotton cultivation spread from India across Asia to form other poles of production and trade with which India interacted. It was around year $1000 \mathrm{CE}$ when cotton became a successful crop in China, the Middle East and Africa. Second, such a process was limited not just by environmental constraints but also by the capacity of the receiving areas to learn and put into practice techniques and technologies that transformed cotton from a botanical rarity into a raw material for a flourishing industry. The spread of spinning and weaving technologies across most of Asia and Africa - and to a certain extent also Europe - meant the development of a new economic sector and changes to both the agrarian and manufacturing economies of Eurasia. Finally, products also diffused across 
space. Indian cottons were appreciated for their visual and tactile properties and ensured for India a central role in global trade. However the 'diffusion of artefacts' was one also based on inspiration and copying, with the design and aesthetics of Indian cloth being appropriated and reinterpreted in different areas of Afro-Eurasia.

\section{Cotton and Divergence}

My own concerns have been to understand how cotton was central to the creation of a 'new global system' increasingly presided over by Europe, not Asia. As previously said, this is a story that has been normally narrated in terms of the industrialisation of Europe. However, I argue that technological development was just one among the many factors explaining this transition. My research underlines the importance of raw materials, markets for products and consumers' preferences as well.

This agenda has been influenced by a 'hot topic' in global history: the differing economic trajectories of Asia and Europe over the past five hundred years (Figure 3). These figures come from one of Angus Maddison's pioneering attempts at quantifying GDP in different parts of the world and in different eras. As such they should be viewed with caution due to the lack of reliable data. However, they provide an explanation for a couple of important topics that have dominated the global economic history agenda over the past two decades. First, the concept of divergence as proposed by Ken Pomeranz in his eponymous book published in 2000 in which he argued that the two extremes of the Eurasian landmass 'diverged' economically sometimes, he says, after 1750, producing a gap that widened between the 'rich' and the 'poor' parts of the world between the mid eighteenth century and the second half of the twentieth century.

The second topic of debate is about 'convergence'. This is not part of the agenda of history but belongs to the debate on globalisation. Essentially it deals with the narrowing of the gap, its eventual closure and inversion. This is explained by the rise of China and India once again, cheap manufacturing, and in particular textile and clothing and other consumer goods seems to be central to this narrative.

Behind this curve lies one of the most complex problems in recent economic history. There is a certain amount of disagreement over the chronology and intensity of these processes, in particular whether Europe was already more developed than China or India in c. 1500. There is also a big debate on what is going to happen next: whether the US will remain an economic and political hegemonic; and whether China will be able to reshape the global system, in particular the system of production, something that has not yet happened. Yet, one has not to forget the necessity to explain the 'in between'. No one will deny the fact that today Europeans are on average fourteen times richer than ten generations ago. Not just that, but we are also globally ten times more numerous (in Europe possibly five-six times more numerous than three centuries ago). The wealth of the world has multiplied exponentially over the past three centuries, something that had not happened since the invention of agriculture. However this increase of wealth has not been equally distributed. 


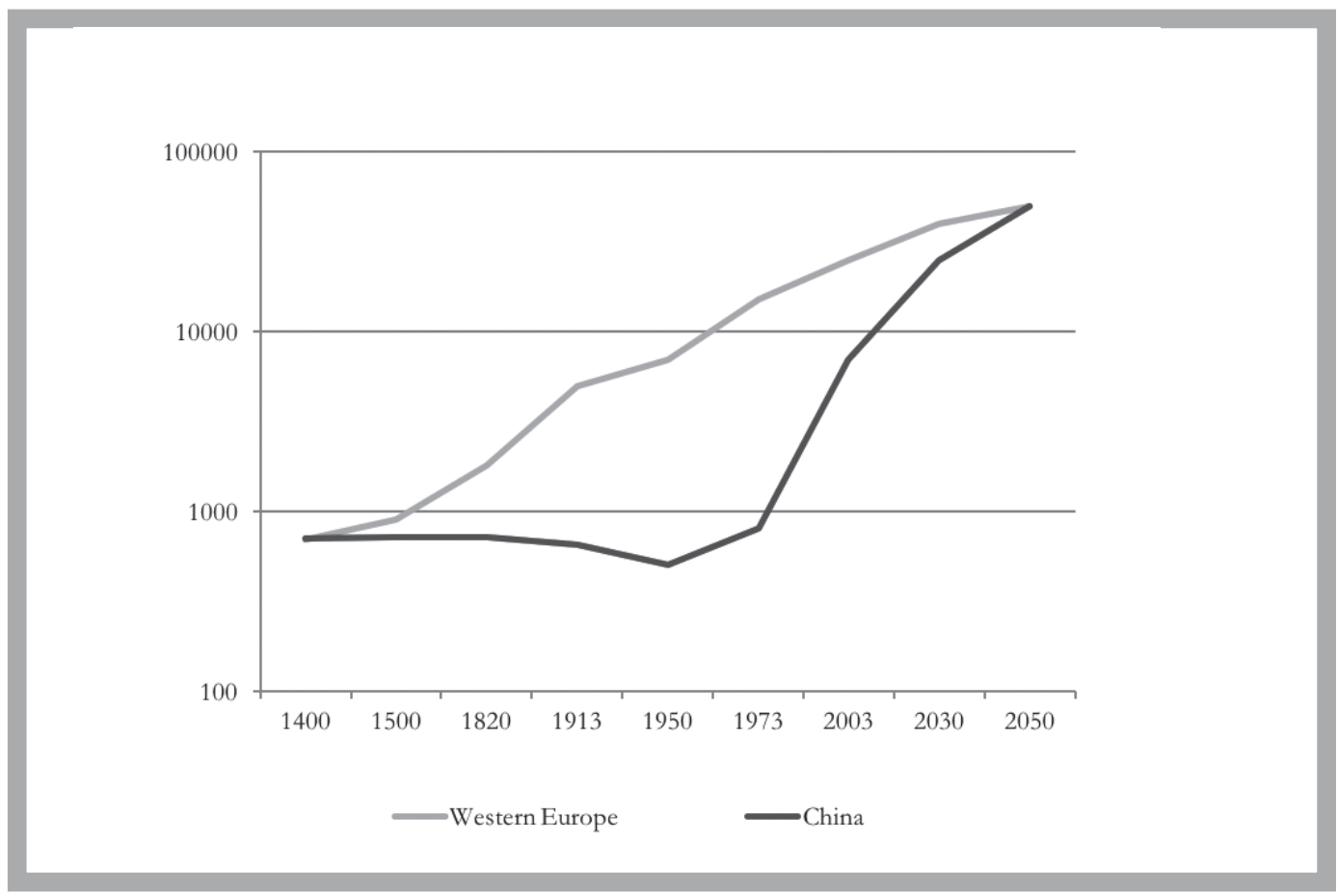

Figure 3. Comparative levels of China / Western Europe GDP per Capita, 1400-2050 (in 1990 dollars; log. scale).

Source: Angus Maddison, The World Economy: A Millennial Perspective (Paris: Development Centre Studies, 2001), p. 44.

Today's poor countries are much poorer compared to the rich countries than three centuries ago. In this sense, divergence is the correct expression to identify the fact that part of the world has moved to a higher plateau of prosperity. This we can confidently say has been until recently the Western World with its antipodean offshoots of Australiant and the West in the East: Japan.

Why has this happened? Over the last century explanations ranged between two poles: that of the 'Exceptionalism of the West' and the idea that it all happened because of 'contingencies' (incidents of history). There is a gradient of 'agency' in the process of divergence on the part of the West. Exceptionalism tends to emphasise that Europe had something special that no-one else had (a special culture or religion - Weber; a special technological creativity - Landes; a special political ability to conquer - Jones, etc.). Contingencies are lucky coincidences. Europe had good and cheap reserves of coal, as noted by Pomeranz, and there has also been a more recent emphasis on Europe's good institutions. ${ }^{8}$

\footnotetext{
${ }^{8}$ Among the many see: James M. Blaut, The Colonizer's Model of the World: Geographical Diffusionism and Eurocentric History (New York: Guilford Press, 1993); David S. Landes, The Wealth and Poverty of Nations: Why Are Some So Rich and Others So Poor? (New York: W.W. Norton, 1998); E. L. Jones, The European Miracle: Environments, Economies, and Geopolitics in the History of Europe and Asia (Cambridge: Cambridge University Press, $3^{\text {rd }}$ ed. 2003); Ian Morris, Why the West Rules - For Now: The Patterns of History, and What They Reveal About the Future (New York: Farrar, Straus and Giroux, 2010); Niall Ferguson, Civilization: The West and the Rest (London: Allen Lane, 2011).
} 
One should note that today exceptionalism is out of fashion and politically incorrect. Our 'great inventor' as portrayed in the 1870s Japanese print is therefore equally out of fashion as it implied that Europe had inventive minds (or more generally a culture of invention) that other cultures did not have.

In my work I claim that there was nothing distinctive about Europe that made it more likely to become the rich, rather than the poor part of the world. However, I emphasise the fact that it was Europe's relations with other parts of the world that started a long process of change: Europeans launched into both exploration and the understanding of the world beyond their continent that brought about both intentional and unintentional outcomes. I call this a process of 'learning' (a rather unfortunate label I later realised), meaning that Europe had to acquire knowledge of cotton textiles in terms of production, trade and consumption, as well as in understanding the potential of the fibre.

This was a long process. Starting from having little familiarity of the cotton fibre and the use of cotton textiles, the European chartered companies provided useful knowledge in order to engage with a complex variety of cotton fabrics that they purchased in India: Europeans had to learn how to successfully trade and market such fabrics. This was a necessary - although not sufficient - condition for Europe's eventual engagement in the production of such products at home and their trade within the Atlantic Ocean. But learning involved consumers as well as traders. Unlike much of the literature, I argue that consumers in Europe (and elsewhere for that matter) did not seize the opportunity to purchase novel fabrics such as cotton textiles. ${ }^{9}$ Quite the opposite, they had to be convinced about the appeal of cotton. Cultural historians have alerted economic historians to the importance of consumption. Indeed the history of consumption has been over the past couple of decades an arena of wide-ranging research that has led some historians to claim the existence of a consumer revolution to counterbalance the more production-led industrial revolution. Economic historians have done their best - and failed - to consider consumption as an endogenous variable.

Both cultural, social and indeed economic history seem to agree on the dynamism brought about by changes in patterns of consumption in Europe in the seventeenth and eighteenth centuries, something that I dispute in the case of cotton textiles. It took the best part of a century for cotton to become fully integrated into the consuming patterns of Europeans - a process that had to be aided by the East India companies through trialand-error and that was opposed by strong textile lobbies, especially those protecting the interests of wool and silk textile producers.

My analysis gives a great deal of space to consumers whom I see as the ultimate arbiters of production. The consumption of calicoes and chintzes became important not just in Europe. Atlantic markets provided an entirely new space for these Asian fabrics and their European

${ }_{9}^{9}$ This argument was originally presented in The Indian Apprenticeship: the Trade of Indian Textiles and the Making of

European Cottons. In Riello and Roy, eds., How India Clothed the World, pp. 307-46. 
imitations in which to thrive. Cotton textiles changed the dress of African consumers and slaves in the Americas. They allowed the development of new production centres in places such as Manchester in England and Rouen in France whose production of cheap copies of Indian cloths was nearly totally sold to African and American consumers.

This in turn allowed for technological experimentation, not in spinning as classic narratives of industrialisation suggest, but in the printing and painting of cloth. Some serious attempts to replicate processes of production of Indian cotton textiles especially in printing and dyeing led to the creation of a thriving cotton printing industry in Europe a century before Arkwright's introduction of new spinning technologies. ${ }^{10}$

The process of learning involved however also the procurement of the raw material. Unable to cultivate it at home, Europeans drew from the experience of sugar and set up a new form of agrarian unit outside the borders of the European continent: the slave plantation. In this case the relationship between cotton and other commodities (sugar but also coffee, cocoa, indigo etc.) is of fundamental importance (Figure 4). Once again, the plantation economy was not the ultimate goal of European endeavour but emerged over time as a viable solution to the scarcity of raw cotton that had plagued European textile manufacturing since the middle ages.

In explaining what Europeans had to learn, I made the conscious choice of 'going backward', that is to say starting with the final commodity - what the European wanted and encountered as traders in the Asian Ocean - and finish with raw cotton. It was over a period of a couple of centuries that Europeans merchants and entrepreneurs came to master a system that replaced different parts of a global commodity chain. Merchants started by importing finished cloth and then trained consumers to appreciate it; then manufacturers started printing on imported white cloth (as this allowed designs and colours better suited to local European customers) and in doing so learned the finishing stages. Then they started thinking about producing their own cloth, first by getting hold of raw materials and eventually also by finding a way to spin and weave such cloth.

This process of 'learning' was protracted. It has nothing of the triumphal narrative of European ascendancy. In fact Europeans were late-comers and failed miserably several times. Unlike narratives of divergence that claim the economic success of Europe to be attributable to one factor, I see Europe's economic transformation as the layering of different factors that include direct access to Indian calicoes and chintzes; the ability to integrate these fabrics into European patterns of consumption; the capacity to sell them outside Europe (Atlantic markets) and the slow acceptance of cotton that made it possible for Europe to engage with this new commodity and material, eventually making it part of its own economy and patterns of consumption.

\footnotetext{
${ }^{10}$ See also Giorgio Riello, "Asian Knowledge and the Development of Calico Printing in Europe in the Seventeenth and Eighteenth Centuries," Journal of Global History 5/1 (2010): 1-28.
} 


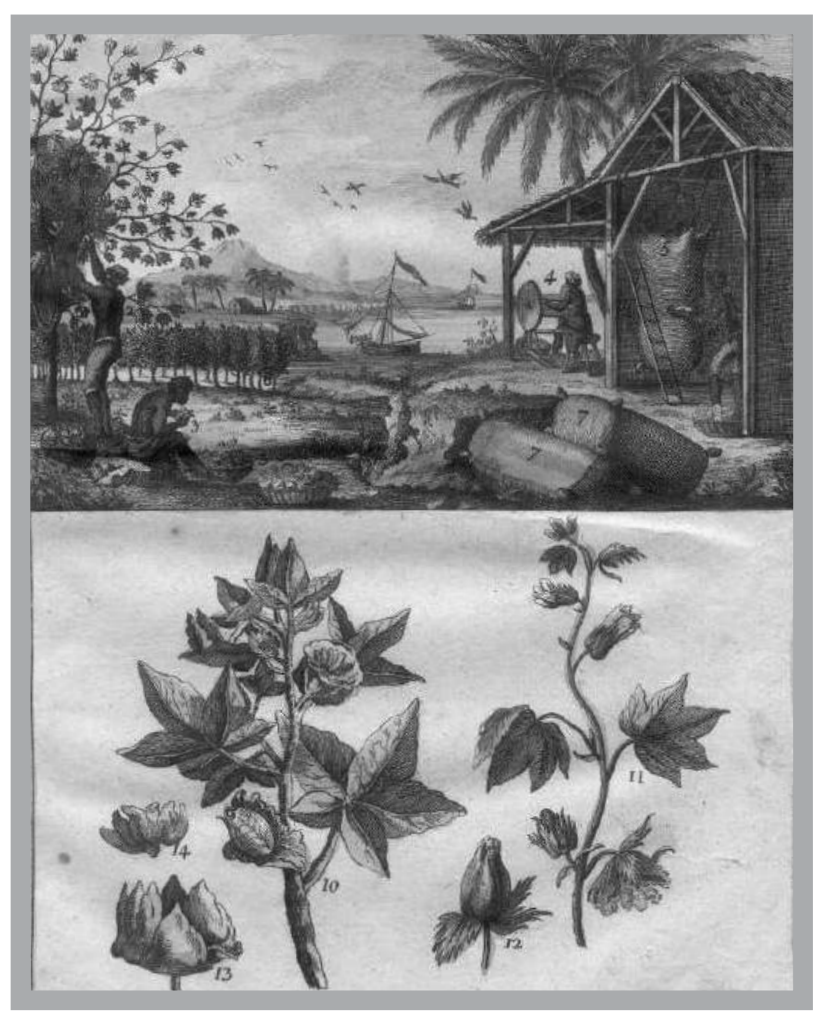

Figure 4. 'Coton', plate VIII of plate from M. Chambon, Le commerce de l'Amérique par Marseille (Avignon, 1764). Private collection.

\section{Cotton and Industrialisation Revised}

Why didn't Europe become yet another area among the many world areas in which cotton spinning and weaving were carried out? How did this process of 'learning' mature into the structuring of something quite new in Europe? My response here whilst acknowledging the role of technology, pays attention to other factors as well. Unlike other world areas, the European system did not cultivate its own raw cotton. Climate simply did not allow that. The commodity chain had to be geographically broken as all raw materials had to be imported from another continent. If there is something unique about the story of cotton, it is not Arkwright's machine, but the fact that for the first time in human history a very large sector of a nation's (indeed a continent's) economy came to be totally reliant on materials from another continent. This was the beginning of what Alfred Crosby calls 'ecologic imperialism'. I am not saying that cotton was free or that it was manna from heaven. Cotton for the first time disconnected the agrarian and the manufacturing economies. It allowed an expansion of the manufacturing economies of European countries on a scale that would have been either impossible or disastrous if resources were to be found only internally in England or Europe.

This is a tricky argument from a historical point of view that can only be proven through counterfactual methodologies. In my book I consider an industrial revolution in England 
and in Europe with no cotton - therefore with the same quantity of cloth made of wool or linen. The result is that there would have not been any industrial revolution as we know it. Essentially the elasticity of supply of a vegetable fibre was far superior to an animal fibre like wool or to another vegetable but labour-intensive fibre as flax was. Even more interesting is to imagine a world in which all the cotton was produced by peasants (or slaves) in Europe, something that I claim would have changed European agrarian organisation beyond recognition. Such a counterfactual history might appear somewhat laughable but in reality one might say that the harsh European climate avoided a path of economic development that would have been less conducive and surely less 'revolutionary' than what happened.

I claim that the revolutionary nature and modernity of cotton was in the fibre. Yet, any sensible economic historian could point out that at the end of the day machines made the difference. One data might be sufficient to highlight this point: in the fifty years between 1780 and 1830 the production cost of a yard of calico cloth fell by 83 percent. Cotton textile production increased tenfold between 1770 and 1790 and tenfold again in the following dozen years. Economic historians see this incredible growth as the result of the application of new technologies, something that is hard to dismiss and an opinion I do not contend with. Yet as to why British and later European producers embraced machinery is hard to explain. My explanation is that technological innovation was sought after but that there was no overall plan or even understanding that it might lead to massive increases in productivity. If there was really an overall rationale in increasing productivity, why not look for technological innovation in woollen production - the major European textile sector? Why instead focus on a small - and one might say insignificant - sector such as cotton manufacturing?

My view of technological development follows a different explanation, put forward by my colleague Maxine Berg. She claims that the quality of products was key both for governments and entrepreneurs as competitiveness was a function of excellence in manufacturing. The interpretation is that technologies were sought after in order to produce a product that was as good as the Indian imported cloth.

In this sense the story of the rise of cotton manufacturing in Europe as a whole was not set within its own borders. The terms of the debate on how best - and even more importantly, if it was desirable - to develop cotton textile production in Europe were explicitly 'global'. For example, the textile producers and traders of Rouen - France's leading cotton centre in the mid eighteenth century - wrote a frank report underlining the weaknesses of the country's cotton industry compared to its Indian competitors.

This image from Chambon (Figure 5), to be found later in the eighteenth century in the Encyclopedie, supports the argument that many contemporaries saw human capital, not technological innovation, as the solution to compete with India. This is why in 1784 the French government under the coordination of the intendant du commerce Jacques-MarieJerome Michau de Montaran, organised for fifty skilled artisans from the Coromandel coast to relocate to France. They arrived in Thieux (a couple of miles from present-day Charles de Gaulle Airport) in October 1785. 
The project was aimed at training local apprentices in the practices of spinning and weaving adopted by the Indian workmen. Results were disastrous, to say the least. The sickly and insubordinate Indians managed to produce cloth worth 12,000 livres against a cost of 41,000 livres spent to support them. None of the apprentices completed their term and the Indian artisans were sent back to the Coromandel at the end of $1787 .{ }^{11}$ This is a nice vignette but it also tells us there was no pre-established rationale towards increasing productivity and that even if increased productivity was sought after, technology might not have been seen as the solution.

\section{Conclusion: A New Global System}

How did the world that cotton created look like once cotton textile manufacturing became the most important sector of Western economies? Sven Beckert, in his recent book, sees it as a capitalist world dominated by force (violence and exploitation) and power (especially of the US as the prime producer of raw cotton). My work is more interested in understanding the world of manufacturing and consumers. Whilst not denying the evils of slavery and the profits of raw cotton production, my interest is in understanding how and why cotton textiles continued to be such prized commodities worldwide.

In the same way in which calicoes and chintzes were continuously changed, adapted and modified during the centuries to respond to consumer demand and fashion, so the industrial cottons produced in the mills of Lancashire had to be 'reinvented' in order to be successful global commodities. This was done materially and by selling at low prices. But here the more nuanced forms of cultural power are also important. Imperialism imposed new cultural models that in turn heavily influenced sartorial models: this is part of a history of what we might call the 'globalisation of western attire and consumption'.

In my book I claim that the West reshaped not just production and trade but also the logic of the system. It created a global system of trade, consumption and manufacturing that I see as 'centripetal' in nature, one based on the capacity of the centre to attract resources and profits towards its productive and commercial core, rather than a 'centrifugal' one based instead on processes of diffusion of resources, technologies, knowledge and sharing of profits and the emergence of several industries around the world.

The new system was one of competition and exclusivity, rather than cooperation and symbiosis; it was based on direct connections - often coordinated by the rising European financial centres - rather than loose areas of exchange based on dynamics nodes. But most of all it was a system whose prosperity was based on forms of intense global exploitation of natural resources and markets. And in this sense formal or informal colonialism might be seen as the political face of this.

${ }^{11}$ See Riello, Cotton, p. 217. 


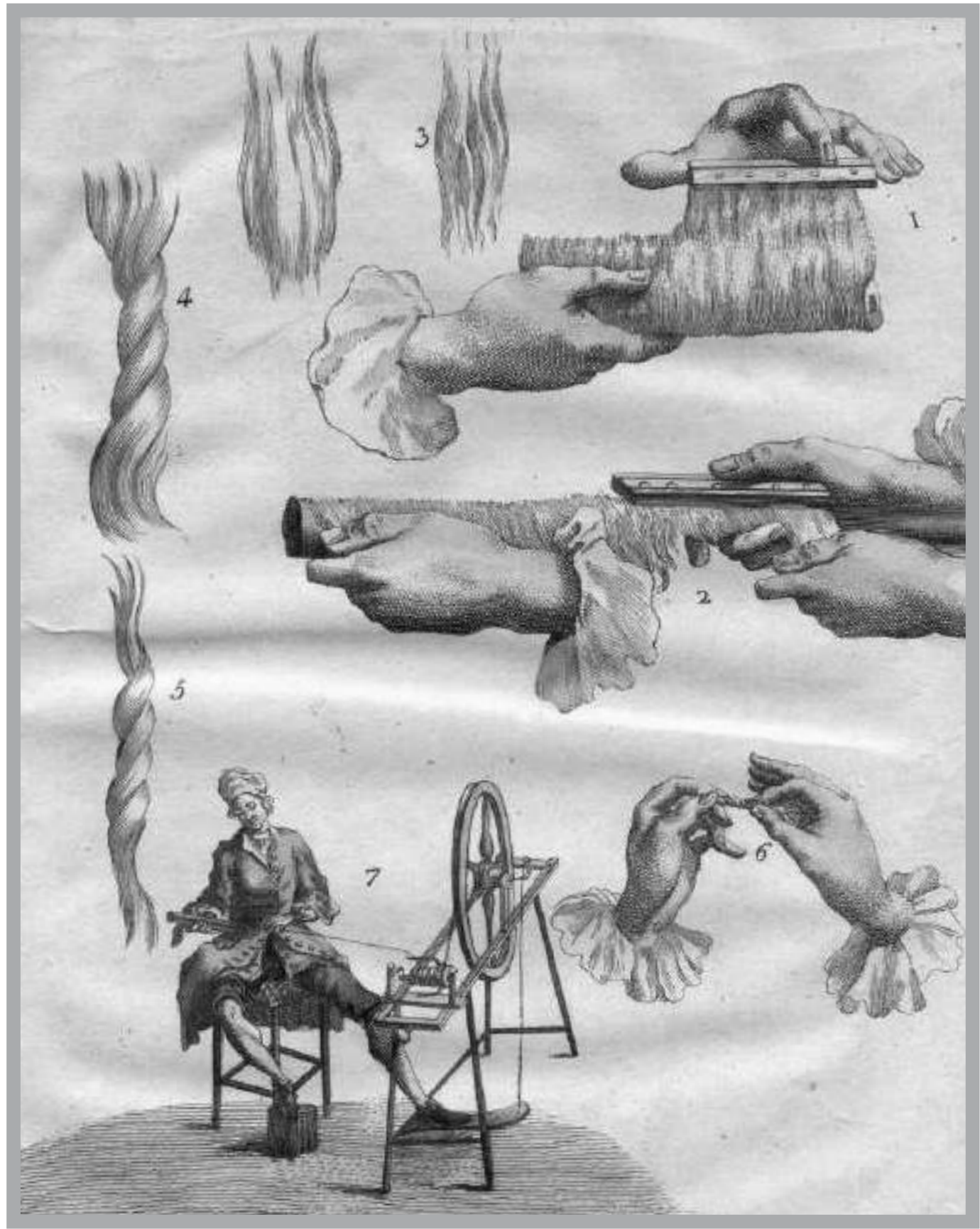

Figure 5. 'Coton', plate IX from M. Chambon, Le commerce de l’Amérique par Marseille (Avignon, 1764). Spinning was portrayed as an activity based on skills, thus visualising the gesture of a hand next to a machine for reeling. Private collection. 


\section{Bibliography}

Beckert, Sven. Empire of Cotton: A Global History. London: Vintage, 2015.

Blaut, M. James. The Colonizer's Model of the World: Geographical Diffusionism and Eurocentric History. New York: Guilford Press, 1993.

"The West and the Rest Revisited: Debating Capitalist Origins, European Colonialism, and the Advent of Modernity." Canadian Journal of Sociology 31/4 (2006): 403-44.

DuPlessis, Robert. The Material Atlantic: Clothing, Commerce, and Colonization in the Atlantic World, 1650-1800. Cambridge: Cambridge University Press, 2015.

Ferguson, Niall. Civilization: The West and the Rest. London: Allen Lane, 2011.

Ghosh, Shami. “The 'Great Divergence', Politics, and Capitalism”. Journal of Early Modern History, 19/1 (2015): 1-43.

Hobsbawm, Eric. Industry and Empire: From 1750 to the Present Day. London: Penguin, 1999.

Jones, E. L. The European Miracle: Environments, Economies, and Geopolitics in the History of Europe and Asia. Cambridge: Cambridge University Press, $3^{\text {rd }}$ ed. 2003.

Landes, S. David. The Wealth and Poverty of Nations: Why Are Some So Rich and Others So Poor? New York: W.W. Norton, 1998.

Morris, Ian. Why the West Rules - For Now: The Patterns of History, and What They Reveal About the Future. New York: Farrar, Straus and Giroux, 2010.

O'Brien, K. Patrick. "Historical Foundations for a Global Perspective on the Emergence of a Western European Regime for the Discovery, Development, and Diffusion of Useful and Reliable Knowledge”. Journal of Global Histoy, 8/1 (2013): 1-24.

Parthasarathi, Prasannan. "Review Article: The Great Divergence." Past \& Present 167 (2002): 275-93.

Why Europe Grew Rich and Asia did Not: Global Economic Divergence, 1600-1850. Cambridge: Cambridge University Press, 2011.

Pomeranz, Kenneth. The Great Divergence: China, Europe and the Making of the Modern World Economy. Princeton: Princeton University Press, 2000.

Riello, Giorgio and Prasannan Parthasarathi. (eds.), The Spinning World: A Global History of Cotton Textiles, 1200-1850.Oxford: Oxford University Press, 2009.

Riello, Giorgio and Tirthankar Roy. (eds.), How India Clothed the World: The World of South Asian Textiles. Leiden: Brill, 2009.

Riello, Giorgio. "Asian Knowledge and the Development of Calico Printing in Europe in the Seventeenth and Eighteenth Centuries". Journal of Global History 5/1 (2010): 1-28.

Cotton: The Fabric that Made the Modern World. Cambridge: Cambridge University Press, 2013.

Rosenthal, Jean-Laurent and R. Bin Wong. Before and Beyond Divergence: The Politics

of Economic Change in China and Europe. Cambridge MA: Harvard University Press, 2011. 